\title{
Maturation stages of fruit development and physiological seed quality in Physalis peruviana ${ }^{1}$
}

\author{
Estágios de maturação no desenvolvimento de frutos e qualidade fisiológica de \\ sementes de Physalis peruviana
}

\author{
Cesar Augustu Gasparetto Sbrussi ${ }^{2 *}$, Claudemir Zucareli ${ }^{3}$, André Mateus Prando ${ }^{2}$ e Bruna Vicentin de Almeida \\ Barbosa da Silva ${ }^{3}$
}

\begin{abstract}
In fleshy fruits such as the Physalis, in which the seeds are the main form of propagation, there is disagreement about the appropriate physiological stage for harvesting in order to obtain high-quality seeds. The objective of this study was to determine the stage of maturation of Physalis peruviana, using the colouration of the fruit and calyx, and relative to the physical aspect of the fruit and the physiological aspect of the seeds. The following five stages of maturation were studied: green calyx and fruit (A); green calyx and yellow fruit (B); yellowish-green calyx and yellow fruit (C); straw-coloured calyx and yellow fruit (D); straw-brown calyx and intensely yellow fruit (E). Physical evaluations were determined using the diameter, length and dry-weight of the fruit, and the 1000-seed weight and water content. The physiological characteristics of the seeds were determined by germination testing, seedling dry weight, germination speed index, seedling emergence in the field and emergence speed index. In Physalis peruviana, the diameter, length and dry weight of the fruit increased with the increase in physiological maturity. The maturation stage did not affect the percentage of germination or seed vigour in Physalis peruviana.
\end{abstract}

Key words: Uchuva. Germination. Exotic fruits. Climacteric.

\begin{abstract}
RESUMO - Em frutos carnosos como o Physalis, em que as sementes são a principal forma de propagação, há divergências quanto ao estágio fisiológico adequado de colheita para obtenção de sementes de qualidade. Objetivou-se neste trabalho determinar o estágio de maturação, através da coloração do fruto e cálice e em relação aos aspectos físicos dos frutos e fisiológicos das sementes de Physalis peruviana. Foram estudados cinco estágios de maturação: cálice e frutos verdes (A); cálice verde e fruto coloração amarelo (B); cálice verde-amarelado e fruto amarelo (C); cálice palha e fruto amarelo (D); cálice palha-marrom e fruto amarelo intenso (E). As avaliações físicas foram determinadas por meio do diâmetro, comprimento e massa seca dos frutos e teor de água e massa de mil sementes. As características fisiológicas das sementes foram determinadas pelo teste de germinação, massa seca de plântula, índice de velocidade de germinação, emergência das plântulas no campo e índice de velocidade de emergência. O diâmetro, comprimento e massa seca dos frutos de Physalis peruviana foram maiores com maior maturidade fisiológica. Os estágios de maturação não interferiram na porcentagem de germinação e vigor das sementes de Physalis peruviana.
\end{abstract}

Palavras-chave: Uchuva. Germinação. Frutos exóticos. Climatério.

\footnotetext{
*Autor para correspondência

Recebido para publicação em 30/08/2011; aprovado em 12/02/2014

Pesquisa realizada na Universidade Estadual de Londrina com recursos da própria instituição

${ }^{2}$ Programa de Pós-Graduação em Agronomia, Universidade Estadual de Londrina, Londrina-PR, Brasil, cesarsbrussi@yahoo.com.br, andre. mateus@hotmail.com

${ }^{3}$ Departamento de Agronomia/CCA, Universidade Estadual de Londrina, Caixa Postal 6001, Londrina-PR, Brasil, 86.051-990, claudemircca@uel.br, bru.almeida12@gmail.com
} 


\section{INTRODUCTION}

The Physalis belongs to the exotic group of fruits, and is highly appreciated by consumers with greater purchasing power (FISCHER; ALMANZA, 1993). This fruit is medicinally important due to the presence of vitasteroids, known as physalin (SOUZA et al., 2010), in addition to its nutritional and economic value, making it an excellent choice for both the domestic and international markets (VELASQUEZ; GIRALDO; ARANGO, 2007). It belongs to the Solanaceae family and in Brazil is considered as a refined fruit having high added value. Its commercial cultivation is increasing, mainly in the south of the country (ANDRADE, 2008).

The species originated in the Andes in South America, and is known as Physalis in Europe, North America and Brazil, as Uchuva in Colombia and Hosuky in Japan. It is a perennial, herbaceous plant (TODA FRUTA, 2010), with fruit, known locally in Brazil as camapu mulaca or juá-de-capote (SOUZA et al., 2010), which are fleshy, round and covered with a calyx of five sepals as protection from insects, birds, pathogens and adverse weather conditions (CHAVES, 2006).

The seed is the main form of propagation and, according to Cedeño and Montenegro (2004), in addition to environmental and agronomic factors, the quality of the seeds is one of the factors that influence the production of excellent fruit. Seed quality is associated with the maximum accumulation of dry matter, known as physiological maturity or the point of mass maturity (WAGNER JUNIOR, 2006).

With fleshy fruits, there is disagreement as to the appropriate time for harvesting in order to obtain goodquality seeds. When to harvest may be influenced by external aspects of the fruit such as colour (AGUIAR et al, 2007; GUIMARÃES; BARBOSA, 2007), size (LEONHARDT; TILLMANN; MATTEI, 2001; LOPES; DIAS; PEREIRA, 2005) and splitting (GEMANAQUE et al., 2002).

Melo (2005) reports that the ideal time for harvesting is when the fruit is fully ripe, whereas Carvalho and Nakagawa (2000) recommend collecting the fruit soon after the start of maturation, when the colouration is still greenish. According to Vidigal et al. (2006), the maturation process of the seeds in fleshy fruits such as the Solanaceae, continues after harvesting making early collection of the fruit possible.

In this species, Mazorra e Quintana (2003) found a high percentage of germination (over $90 \%$ ) in seeds from fruit of a greenish-yellow colour, 50 days after fruiting, in the Subia and San Raimundo regions of Colombia. They also report that the storage time of the fruit did not affect the germination percentage of the seeds. While Medina (1985) comments that seeds of Physalis peruviana do not reach physiological maturity at the same time as the fruit, it being necessary to submit them to low temperatures. According to the same author, germination is higher the longer the period of seed conservation (MEDINA ,1985).

Determining the maturation of a species is important in order to get good-quality seeds, with the aim of minimising physiological losses while still in the field and obtaining plants of good development and productivity (VIDIGAL et al., 2006).

In view of the above, the objective was to determine the maturation stage by fruit and calyx colouration in relation to the physical appearance of the fruit and the physiological appearance of the seeds in Physalis peruviana.

\section{MATERIAL AND METHODS}

The work was carried out at the Laboratory for Seed Analysis and in a greenhouse of the Department of Plant Production of the State University of Londrina (UEL), in the state of Paraná, Brazil. Physalis seeds were obtained from plants grown on the School Farm at UEL, located at $23^{\circ} 18^{\prime} \mathrm{S}$ and $51^{\circ} 09^{\prime} \mathrm{W}$, at an altitude of $560 \mathrm{~m}$. The climate is classified as Cfa (humid mesothermal) according to the Köppen-Geinger classification.

The fruits were harvested and taken to the laboratory, where they were selected into five stages of maturation: green calyx and fruit (A); green calyx and yellow fruit (B); yellowish-green calyx and yellow fruit (C); straw-coloured calyx and yellow fruit (D); strawbrown calyx and bright yellow fruit (E) (Figure 1). The experimental design was completely randomised with five treatments and four replications.

The physical characteristics of the fruit were determined in a sample of 15 fruits selected at random, by measurement of the diameter and length of the fruit $(\mathrm{mm})$ at different stages of maturation. The dry weight and moisture content of the variables under study were also determined in an oven, at $65 \pm 5{ }^{\circ} \mathrm{C}$ to constant weight.

A blender was used for extracting the seeds, separating the peel, pulp and seed by difference in density; the seeds being deposited on the bottom of the container due to their greater density. They were then selected, washed and dried at room temperature.

The seeds were evaluated using the following variables: Water content - four replications of approximately $0,500 \mathrm{~g}$ were used, placed in an oven 
Figure 1 - Stages of maturation: green calyx and fruit (A); green calyx and yellow fruit (B); yellowish-green calyx and yellow fruit (C); straw-coloured calyx and yellow fruit (D); straw-brown calyx and bright yellow fruit (E)

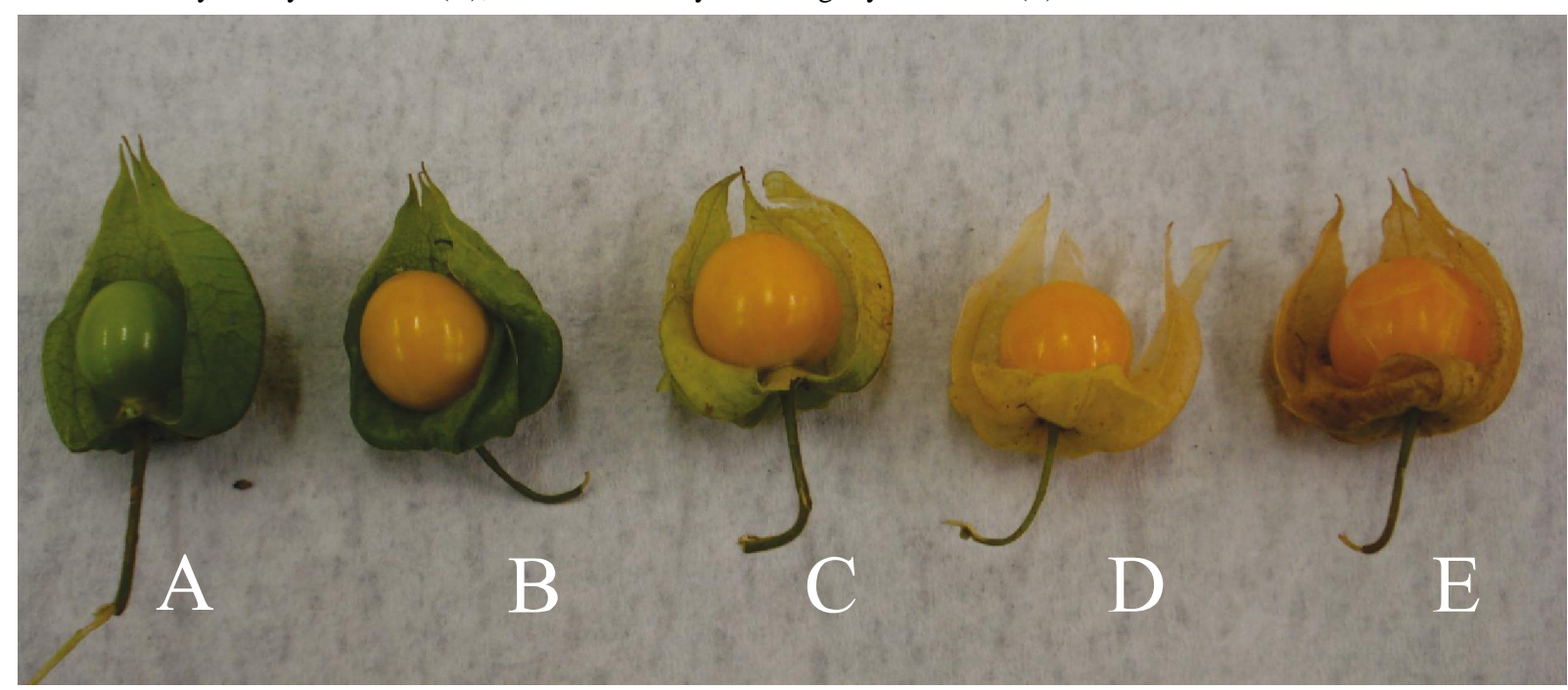

at $105 \pm 3{ }^{\circ} \mathrm{C}$ for 24 hours (BRASIL, 2009); 1000 Seed Weight - determined with eight replications of 100 seeds, as described in the Rules for Seed Analysis (BRASIL, 2009); Germination test - carried out on four replications of 100 seeds, packed into 'gerbox' plastic boxes containing moistened paper in the ratio of 2.5 times the weight of the dry substrate. The temperatures and luminosities were alternated between $30^{\circ} \mathrm{C}$ with light for 16 hours and $20{ }^{\circ} \mathrm{C}$ without light for eight hours, with evaluations carried out seven and 28 days after planting (BRASIL, 2009); Seedling dry weight - obtained from the previous evaluation after drying at $65 \pm 5{ }^{\circ} \mathrm{C}$ to constant weight, with the results expressed in grams (NAKAGAWA, 1999); Germination speed index (GSI) - obtained by a daily count starting from germination of the first seedling, with the GSI being calculated according to Maguire, cited by Nakagawa (1999); Seedling emergence - conducted in a greenhouse using four replications of 50 seeds, sown in styrofoam trays, with Plantimax ${ }^{\circledR}$ commercial substrate. For the evaluation, seedlings which had emerged 28 days after sowing were considered, and expressed as a percentage (NAKAGAWA, 1999); Seedling emergence speed index in the field (SEI) - using the test for seedling emergence, where daily counts were taken after emergence of the first seedling. The calculation was carried out following the methodology used to determine the GSI.

Variance analysis was carried out on the data from the variables under study, and the averages were compared by Tukey test at $5 \%$ significance (BARBIN, 2003) employing the SISVAR statistical software.

\section{RESULTS AND DISCUSSION}

The characteristics of diameter, length and dry weight of the fruit differed significantly according to the different stages of maturation, as seen in Table 1.

The diameter and length of the fruit showed similar variation with the lowest values seen at stage A (calyx and fruit of green colouration) and the highest values obtained at stages D and E (straw-coloured calyx and yellow fruit and straw-brown calyx and bright yellow fruit) respectively. It can be seen that the diameter and length of the fruit increased with maturation (Table 1).

In seeds of the sabiá (Mimosa caesalpiniaefolia) (ALVES, 2003) and quaresmeira (Tibouchina granulose) (LOPES; DIAS; PEREIRA, 2005), the size of the fruit proved useful as a maturation index. In the same way, the physical differences seen in the length and diameter of the physalis fruit showed that classification using the colouration of the epidermis and calyx can be useful in assessing seed quality at different stages of maturation.

Lima et al. (2009), when studying the physicochemical characteristics of physalis in five different colourations of calyx and conducting system, obtained greater fruit diameter at phase five of calyx colouration (brownish yellow), this however only differed from the fruit at stage 1 (green calyx). Mazorra e Quintana (2003) observed that the longitudinal and transverse diameters of the physalis fruits increase up to the last physiological maturation stage. According to Ávila et al. (2006), green fruits have smaller diameters due to the stage of physiological development. It is 
noteworthy that fruits with incomplete development may have badly formed seeds of low vigour.

For fruit dry weight, lower values were seen only at the first stage (A) and remained constant at the other stages of maturation (Table 1). Between stages B and E, the average for fruit dry weight did not differ statistically. This result was observed by Lima et al. (2009), with a lower weight for the physalis fruit at the first maturation stage (green calyx). As reported by Costa et al. (2004), the weight of the fruits is linearly related to their degree of development and maturation.

In Table 2 can be seen the averages for 1000 seed weight and seed moisture content for the different stages of fruit maturation.

It was observed that there was no significant increase in 1000 seed weight as maturation progressed from stage A to stage B (green calyx and yellow fruit), when the greatest seed weight was reached. According to Silveira, Villela e Tillmann (2002), seed weight is one of the morphological causes that may affect the vigour and influence the physiological quality of the seeds. From stage B, there was a reduction in the 1000 seed weight up to the last maturation stage (E), where the lowest value for this can be seen.

According to Dias (2001), the multiplication and development after fertilisation of cells from the embryo and reserve tissue, are responsible for a dramatic increase in the size of the seed, reaching a maximum value in a short period of time in relation to the total duration of the maturation period. The same author reports that the size of the seed may be reduced once reaching maximum due to water loss by the seeds, which varies according to species.

Although there was no difference in water content between treatments, it can be seen that this presented its greatest value at $\mathrm{B}$, followed by continual decreases until the last stage of maturation, straw-brown calyx and bright yellow fruit (E), in a similar way seen for the values for seed dry weight. Although employed, the water content

Table 1 - Averages for length of fruit, cm (LF), diameter of fruit, cm (DF) and fruit dry weight, g (DW) at different stages of physiological maturity in fruits of Physalis peruviana. Londrina, Paraná, 2011

\begin{tabular}{lccc}
\hline \multirow{2}{*}{ Maturation stage } & \multicolumn{3}{c}{ AVERAGES } \\
\cline { 2 - 4 } & LF $(\mathrm{cm})$ & DF $(\mathrm{cm})$ & DW $(\mathrm{g})$ \\
\hline $\mathrm{A}$ & $1.333 \mathrm{c}$ & $1.453 \mathrm{c}$ & $0.334 \mathrm{~b}$ \\
$\mathrm{~B}$ & $1.633 \mathrm{~b}$ & $1.753 \mathrm{~b}$ & $0.832 \mathrm{a}$ \\
$\mathrm{C}$ & $1.746 \mathrm{ab}$ & $1.860 \mathrm{ab}$ & $0.921 \mathrm{a}$ \\
$\mathrm{D}$ & $1.840 \mathrm{a}$ & $1.980 \mathrm{a}$ & $0.923 \mathrm{a}$ \\
$\mathrm{E}$ & $1.846 \mathrm{a}$ & $1.986 \mathrm{a}$ & $0.926 \mathrm{a}$ \\
$\mathrm{CV}(\%)$ & 10.15 & 8.14 & 27.18 \\
\hline
\end{tabular}

Averages followed by the same letter in the columns do not differ by Tukey test $(\mathrm{P}<0.05)$. A: green calyx and fruit. B: green calyx and yellow fruit. C: yellowish-green calyx and yellow fruit. D: straw-coloured calyx and yellow fruit. E: straw-brown calyx and bright yellow fruit

Table 2 - Average values for seed water content as a percentage (WC) and 1000 seed weight in grams (TSW) at different stages of maturation in Physalis peruviana. Londrina, Paraná, 2011

\begin{tabular}{|c|c|c|}
\hline \multirow{2}{*}{ Maturation stage } & \multicolumn{2}{|c|}{ 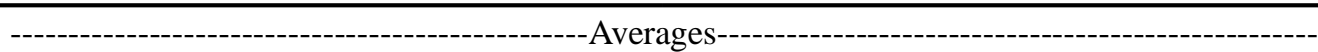 } \\
\hline & $\mathrm{WC}(\%)$ & TSW (g) \\
\hline A & 12.00 & $0.1044 \mathrm{ab}$ \\
\hline B & 12.25 & $0.1069 \mathrm{a}$ \\
\hline $\mathrm{C}$ & 12.00 & $0.1029 \mathrm{~b}$ \\
\hline $\mathrm{D}$ & 11.75 & $0.1033 \mathrm{ab}$ \\
\hline $\mathrm{E}$ & 11.00 & $0.1010 \mathrm{~b}$ \\
\hline $\mathrm{CV}(\%)$ & 8.41 & 2.44 \\
\hline
\end{tabular}

Averages followed by the same letter in the columns do not differ by Tukey test $(\mathrm{P}<0.05)$. A: green calyx and fruit. B: green calyx and yellow fruit. C: yellowish-green calyx and yellow fruit. D: straw-coloured calyx and yellow fruit. E: straw-brown calyx and bright yellow fruit 
of the seeds is not an adequate indicator of physiological maturity, due to environmental and genetic influences (Medeiros et al., 2010). However, according to Silva (2002), when combined with other characteristics, the water content is considered an important index for the maturation process and is suggested as a reference for indicating the physiological condition of the seeds.

According to Carvalho and Nakagawa (2000), physiological maturity is reached when the seed presents maximum dry matter content and also a marked reduction in water content, changes which are visible in the external appearance of the fruit and seeds, culminating in maximum seed germination and vigour. In this context, it can be seen that the physiological maturity of the seeds may have occurred during the change from stage $\mathrm{B}$ (green calyx and yellow fruit) to stage C (yellowish-green calyx and yellow fruit), when the greatest seed dry weight and reduction in water content were recorded respectively.

Medeiros et al. (2010) observed in seeds of the maxixe, the largest increase in seed dry weight at the same time as the greatest reduction in water content, which according to the same author, would suggest a likely indicator of physiological maturity. However, Vidigal et al. (2009) reported that the best seed quality may not coincide with the maximum dry weight.

The physiological characteristics of the seeds as a function of the stage of maturation of the fruit are shown in Table 3. It was found that seeds obtained at the five different stages of maturation did not differ as to percentage and speed of germination or emergence and the emergence rate of seedlings in the field. Alexandre et al. (2006), when studying three different stages of maturation in the germination and development of seedlings of the jabuticaba (Myrciaria cauliflora), observed that the stages of maturation did not significantly influence germination of the seeds.

On the other hand, Mazorra e Quintana (2003) report that with physalis one of the parameters used in the study of maturation has been seed germination, where the highest percentages indicate physiological maturity. Using seeds of Physalis peruviana with seven different stages of fruit colouration in the regions of San Raimundo and Subia in Colombia, the authors obtained evidence of germination 30 days after the start of fruiting (green calyx and fruit), however, with low germination percentages $(35 \%)$.

A low germination percentage at the start of fruit development is due to immaturity, as the protein which is responsible for reserves in the seed is probably not adequately synthesised. According to Mazorra e Quintana (2003), maturity in Physalis fruit is reached 50 days after the start of fruiting (yellowish-green calyx and fruit), when over $90 \%$ germination is seen and the fruit aquires features that guarantee seed propagation and later development.

A high percentage of germination (89\%) was observed in the region of Subia, Colombia, after 40 days of fruiting, with fruit and calyxes still of a light green and green coloration respectively As the present study showed the absence of statistical differences in germination between the five different stages of maturation, as well as the low rates of germination seen in all treatments, unlike those seen by Mazorra e Quintana (2003), the seeds were not treated or disinfected after being dried.

When analysing the dry weight of seedlings for the germination test at 28 days, a significant increase can be seen in the dry weight because of maturation stage $\mathrm{C}$

Table 3 - Mean values for percentage of germination $(\% \mathrm{G})$, germination speed index (GSI), seedling emergence in the field (SEF), speed of emergence index (SEI) and seedling dry weight (SDW) at five different stages of maturation in Physalis peruviana. Londrina, Paraná, 2011

\begin{tabular}{lccccc}
\hline \multirow{2}{*}{ Maturation stage } & \% G & GSI & SEF & SEI & SDW \\
\cline { 2 - 5 } & 80.75 & 7.35 & 78.50 & 3.23 & $0.458 \mathrm{~b}$ \\
\hline A & 71.25 & 5.82 & 81.00 & 3.21 & $0.508 \mathrm{ab}$ \\
B & 72.00 & 6.00 & 74.50 & 3.17 & $0.568 \mathrm{a}$ \\
C & 76.00 & 6.22 & 67.50 & 2.74 & $0.493 \mathrm{ab}$ \\
D & 79.25 & 6.80 & 74.50 & 2.90 & $0.515 \mathrm{ab}$ \\
E & 13.79 & 17.87 & 19.83 & 27.33 & 9.34 \\
CV $(\%)$ & &
\end{tabular}

Averages followed by the same letter in the columns do not differ by Tukey test $(\mathrm{P}<0.05)$. A: green calyx and fruit. B: green calyx and yellow fruit. C: yellowish-green calyx and yellow fruit. D: straw-coloured calyx and yellow fruit. E: straw-brown calyx and bright yellow fruit 
(yellowish-green calyx and yellow fruit), indicating greater vigour and better development (Table 3 ). According to Carvalho and Nakagawa (2000), seeds which are not fully mature may germinate, however they are not as vigorous as those which are physiologically mature.

\section{CONCLUSION}

The diameter, length and dry weight of the fruit of Physalis peruviana were greater with increased physiological maturity. The maturation stage did not affect the percentage of germination or seed vigour in Physalis peruviana.

\section{REFERENCES}

ANDRADE, L. Physalis ou Uchuva: Fruta da Colômbia chega ao Brasil. Revista Rural, n. 38, p. 11-12, 2008.

AGUIAR, F. F. et al. Maturação de frutos de Caesalpinia echinata Lam., pau brasil. Revista Árvore, v. 31, n. 1, p. 1-6, 2007.

ALEXANDRE, R. S. et al. Estádio de maturação dos frutos e substratos na germinação de sementes e desenvolvimento inicial de plântulas de jabuticabeira. Revista Brasileira Agrociência, v. 12 n. 2, p. 227-230, 2006.

ALVES, E. U. Maturação de sementes de sabiá (Mimosa caesalpiniifolia Benth.). 2003. 89 f. Tese (Doutorado em Agronomia/Produção e Tecnologia de Sementes) - Faculdade de Ciências Agrárias e Veterinárias, Universidade Estadual Paulista, Jaboticabal, 2003.

ÁVILA, A. J. et al. Influencia de la madurez del fruto y del secado del cáliz en uchuva (Physalis peruviana L.), almacenada a $18{ }^{\circ} \mathrm{C}$. Acta Agronómica Colombiana, v. 55, n. 4, p. 29-38, 2006.

BRASIL. Ministério daAgricultura, Pecuária e Abastecimento. Regras para análise de semente. Brasília: SNAD/DNDV/ CLAV, 2009. $395 \mathrm{p}$.

CARVAlho, N. M.; NAKAGAWA, J. Sementes: ciência, tecnologia e produção. Jaboticabal: FUNEP, 2000. 588 p.

CEDEÑO, M.M.; MONTENEGRO, D.M. Plan exportador, logistico y de comercilizacion de uchuva al mercado de estados unidos para frutexpo S.C.I. Ltda. Monagrafia de conclusão de curso - Pontificia Universidad Javeriana, Bogotá. 2004. $134 \mathrm{p}$

CHAVES, A. C. Propagação e avaliação fenológica de Physalis sp. na região de Pelotas-RS. 2006. 65 f. Tese (Doutorado em Agronomia) - Universidade Federal de Pelotas, Pelotas, 2006.

COSTA, N. P. et al. Caracterização físico-química de frutos de umbuzeiro (Spondias tuberosa Arr. Câm.), colhidos em quatro estádios de maturação. Bioscience Journal, v. 20, n. 2, p. 65-71, 2004.

DIAS, D. C. Maturação de Sementes. Seed News, v. 5, n. 6, p. 3-4, 2001.

FISCHER, G.; ALMANZA, P. J. Nuevas tecnologias en el cultivo de la uchuva Physalis peruviana L. Agrodesarrollo, v. 4, n. 1-2, p. 294, 1993.

GEMANAQUE, R.C. R.; DAVIDE,A.C.;FARIA, J. M. Indicadores de maturidade fisiológica de sementes de ipê-roxo (Tabebuia impetiginosa (Mart.) Standl.) Cerne, v. 8, n. 2, p. 84-91, 2002.

GUIMARÃES, D. M.; BARBOSA, J. M. Coloração dos frutos como índice de maturação para sementes de Machaerium brasiliense Vogel (Leguminosae - Fabaceae). Revista Brasileira de Biociências, v. 5, n. 2, p. 567-569, 2007.

LEONHARDT, C.; TILLMANN, F. A. V.; MATTEI, V. L. Maturação fisiológica de sementes de tarumã-de-espinho (Citharexylum montevidense (Spreng.) Moldenke - Verbenaceae), no Jardim Botânico de Porto Alegre, RS. Revista Brasileira de Sementes, v. 23, n. 1, p. 100-107, 2001.

LIMA, C. S. M. et al. Características físico-químicas de physalis em diferentes colorações do cálice e sistemas de condução. Revista Brasileira de Fruticultura, v. 31, n. 4, p. 1061-1068, 2009.

LOPES, J. C.; DIAS, P. C.; PEREIRA, M. D. Maturação fisiológica de sementes de quaresmeira. Pesquisa Agropecuária Brasileira, v. 40, n. 8, p. 811-816, 2005.

MAZORRA M. F.; QUINTANA A. P. Desarrollo del fruto y aspectos anatómicos de las estructuras reproductivas de la uchuva (Physalis peruviana L.) en la zona de Subia (Cundinamarca). [Trabajo de Grado]. Bogotá: Facultad de Agronomía, Universidad Nacional de Colombia, Sede Bogotá; 2003.

MEDEIROS, M. A. et al. Maturação de sementes de maxixe maturação fisiológica de sementes de maxixe (Cucumis anguria L.). Revista Brasileira de Sementes, v. 32, n. 3, p. 17-24, 2010.

MEDINA, D. Estudio Morfo - Fisiológico de la semilla de Physalis peruviana (Tomatillo) y el efecto de cuatro sustratos $\mathrm{y}$ dos bioestimulantes en el enraizamiento de esquejes. Tesis Ing. Agrónomo. Universidad Nacional de Cajamarca. Cajamarca, Perú. 1985. 72 p.

MELO, P. C. T. Produção de sementes de tomate: cultivares de polinização aberta ehíbridos. In:CURSOSOBRETECNOLOGIA DE PRODUÇÃO DE SEMENTES DE HORTALIÇAS, 5., 2005, Brasília. Anais... Brasília, 2005. 1 CD-ROM.

NAKAGAWA, J. Teste de vigor baseados no desempenho da plântula. In: KRZYZANOWSKI, F. C.; VIEIRA,R. D.; FRANÇA NETO,J. B.(Ed.).Vigor de semente: conceitos e teste. Londrina: ABRATES, 1999.

SILVA, L. M. M. Maturação fisiológica de sementes de Cnidosculus phyllacanthus Pax \& K. Hoffm. In: Morfologia e ecofisiologia de sementes de Cnidosculus phyllacanthus Pax \& K. Hoffm. 2002.. Tese (Doutorado em Agronomia) - Faculdade de Ciências Agrárias e Veterinárias, Universidade Estadual Paulista, Jaboticabal, 2002. p. 46-61. 
SILVEIRA, M. A. M; VILlELA, F. A.; TILlMANN, M. A. A. Comparação de métodos para avaliação da qualidade fisiológica em sementes de Calêndula Revista Brasileira de Sementes, v. 24, n. 2, p. 24-30, 2002.

SOUZA,C.L.M. etal.Morfologia de sementes e desenvolvimento pós-seminal de Physalis angulata L. Revista Acta Botância Brasílica, v. 24, n. 4, p. 1082-1085, 2010.

VELASQUEZ, H. J. C.; GIRALDO, O. H. B.; ARANGO, S. S. P. Estudio preliminar de la resistência mecánica a la fractura y fuerza de fi rmeza para frut fruta de uchuva ( Physalis peruviana L.). Revista Facultad Nacional de Agronomía, v. 60, n. 1, p. 3785-3796, 2007.
VIDIGAL, D. S. et al. Qualidade fisiológica de sementes de tomate em função da idade e do armazenamento póscolheita dos frutos. Revista Brasileira de Sementes, v. 28, n. 3, p. 87-93, 2006.

VIDIGAL, D. S. et al. Alterações fisiológicas e enzimáticas durante a maturação de sementes de pimenta (Capsicum annuum L.) Revista Brasileira de Sementes, v. 31, n. 2, p. 129-136, 2009.

WAGNER JÚNIOR, A. et al. Influência do estádio de maturação dos frutos e do substrato na formação de "seedlings" de três cultivares de pessegueiro. Revista Brasileira Agrociência, v. 12, n. 2, p. 221-225, 2006. 